\title{
Rubber Agroforestry Systems (RAS) in West Kalimantan, Indonesia: An historical perspective
}

\author{
Eric Penot $^{1}$ and Ilahang ${ }^{2}$ \\ ${ }^{1}$ CIRAD, UMR Innovation, Montpellier France \\ ${ }^{2} \mathrm{SNV}$, Sanggau, Kalimantan, Indonesia
}

\begin{abstract}
In 1994 in the Sanggau/Sintang area in West Kalimantan province, most farmers relied mainly on jungle rubber, an old agroforestry system based on rubber seedling with low productivity, low establishment cost and low maintenance but high biomass and biodiversity. Most farmers at that period wanted to have access to clonal rubber planting material in order to improve their productivity (rubber clones do produce 3 times more than seedlings). The CIRAD/ICRAF/IRRI project called SRAP (Smallholder Rubber Agroforestry project) has set-up in 1994 on farm trials with 60 farmers in order to optimize clonal based new RAS according to local conditions and constraints. When SRAP started (1994/2007), the original objectives were multiple: i) to provide clone and high rubber productivity, ii) to maintain agroforestry practices to profit from positive externalities, and iii) to diversify income through timber, fruits, resins (Gaharu, Damar...) and other forest products (rattan, medicinal plants, forest vegetables etc). In 1997, came in the landscape oil palm estates though the very high and rapid development of private concessions. Oil palm became in the 2000's the main priority for most smallholders. Today, all forest and most local jungle rubber have disappeared to the profit of roughly $2 / 3$ of the area planted with oil palm (estates and smallholder) and $1 / 3$ with clonal rubber for smallholder, either in monoculture or agroforestry. In 2019, CIFOR/FTA program funded a mission to CIRAD to obtain information about the evolution of RAS trials plots evolution in the province of West Kalimantan. The survey provide an idea of the historical and current trend in terms of local farming strategies concerning agroforestry. It raised also the question of clonal planting material availability for replanting and the poor tapping quality that lead to a reduction of the clonal rubber lifespan. Evolution of trials status over the period1994/2019 display the following results: i) Conversion to oil palm ( $20 \%)$ or to clonal rubber monoculture (20 $\%$ mainly in Trimulia in Transdmigration area), ii) with agroforestry systems maintained in RAS 1 or $2(50 \%)$ and iii) evolution to tembawang at the end of rubber lifespan (10\%). We are back to the same problems faced in 1994: poor access to clonal planting material, no training on tapping frequency and practices but with some knowledge on clones and $\mathrm{AF}$ practices. The lessons learned are the following: i) Rubber agroforestry trials came right in time in 1994, with a strong demand from farmers, ii) but oil palm came in 1997 with a very strong pressure from concession companies providing a lucrative alternative to rubber cultivation with full credit (but loss of land) and better return to labor, iii) Interest in agroforestry practices remains high for old men but no interest is witnessed from younger generation, iv) It is now time for rubber replanting but the same old story remains: poor access to planting
\end{abstract}


material), v) no good tapping practices, poor technical information available). These are essential to be able to maximize tree lifespan up to 35 years long.

\section{Introduction}

In 2019, FTA program funded a mission to CIRAD to obtain information about the evolution of rubber agroforestry trials plots that were established in the 1990's with ICRAF/CIRAD in West Kalimantan trough the USAID funding/SRAP/Smallholder Rubber Agroforestry Project (1994/2007) [17]. All villages with on-farm-trials plots established in 1994/1997 have been visited (Kopar, Engkayu, Embaong, Pana and Trimulia in Kabupaten Sanggau except the village of Pariban Baru in Sintang transmigration area. In the visit was also included the village of Sanjan (Kabupaten Sanggau) were former SRDP project farmers were the very first farmers to re-introduce fruit and timber trees within their project clonal rubber initial monoculture. These SRDP farmers provided evidence that combining up to 250 fruit and timber/ha with normal planting density clonal rubber at 550 trees/ha did not have any impact on rubber production [39]. That fact paves the way to set up on-farm-trials to optimize these agroforestry practices trough the SRAP project. All results from SRAP have been presented in a CD rom published in 2004 [35]. The objective of this communication is to provide an idea of the historical and current trend in terms of local farming strategies concerning agroforestry practices.

When the SRAP research program started in 1994 in the area, most farmers relies mainly on jungle rubber, an agroforestry system based on rubber seedling with low productivity but high biomass and biodiversity with very positive externalities [29, 15]. Most farmers wanted to have access to clonal rubber planting material in order to improve their land and labor productivity. Clones do produce three times more than seedlings. The original idea was multiple: i) to provide to farmers access to clone and high rubber productivity, ii) to maintain agroforestry practices to profit from advantages and positive externalities, and iii) to diversify income sources through timber, fruits, resins (such as gaharu/agar wood, damar...) and other forest products (rattan, medicinal plants, forest vegetables etc). Beside on farm trials with various types of agroforestry practices, SRAP did establish village budwood gardens managed by local communities, in association with farmers' private nurseries and grafting training to boost clonal planting material by farmers themselves an improve global access. In 1997, came in the landscape oil palm though the very high and rapid development of private concessions with contract with local farmers who has access generally of 2 ha per family. Oil palm became in the 2000's the main priority for most smallholders.

In 2019 the need to understand i) what happened with RAS, ii) the evolution of farmers strategies concerning oil palm vs rubber as well as about agroforestry practices, iii) the future of agroforestry practices in the 2019/2021 context.

\subsection{Context and history}

\subsubsection{Jungle rubber: the historical rubber system in Indonesia for smallholders}

At the turn of the 19th century, the Sumatra and Kalimantan plains at low altitude were sparsely inhabited with a population density of less than 4 persons $/ \mathrm{km}^{2}$. The population relied mainly on shifting cultivation of upland rice. The introduction of rubber by private Dutch estates in the 1910's triggered a radical change in the landscape evolution but not in farming practices, at least in the beginning. Although estates adopted monoculture right from the beginning, trying to maximize rubber production, farmers immediately saw and exploited the 
possibility of growing rubber in a very extensive way by enriching their fallow ('belukar' in Indonesian) with unselected rubber seedlings that were freely available. Planting rubber during, or after, upland rice demanded only marginal extra work, with no risks and more importantly for local farmers no costs. Farmers immediately saw an opportunity for rubber production and began to collect seeds in estates to plant their own rubber. Unselected rubber proved to be very adaptive to this "new environment", seen from an estate perspective thinking in terms of monoculture, although the original habitat of rubber is the forest in South-America. This system has been called "jungle rubber" (hutan karet) by Indonesian farmers who consider that it was basically a fallow enriched with rubber trees [15].

The advantages of jungle rubber were clear: no cost; no labor required for maintenance during the immature period; and income diversification with fruits, rattan, timber and other non-timber forest products harvested from the agroforest. Jungle rubber have a very high vegetal biodiversity $[1,2,10,21,24]$. Although rubber tapping was delayed compared to rubber monoculture on estates, yields still provided an attractive income as improved planting material (clone appeared only in the 1930/40'). Indirect environmental benefits included soil conservation and rehabilitation of degraded lands. Originally, the adoption of this system did not change farmer practices and, in addition to managing their jungle rubber, farmers continued to slash-and-burn new plots every year. At this stage jungle rubber could be considered as a "fallow enriched with rubber". Such evolution was similar in Sumatra and Kalimantan where more than $90 \%$ of rubber is produced in Indonesia. The case of Kalimantan is slightly different from Sumatra for two reasons; i) population is constituted of Malayu people on sea-shore and river banks and Dayak people in the hinterland in local forest. Dayak farmers relies until the 1960's on forest products and are very keen to maintain fruit, timber and NTFP (Non-Timber Forest Products) production from agricultural activities leading to a very positive sensibility to agroforestry practices and ii) the colonial power controlled effectively Kalimantan in the 1930's only, very late indeed without any negative impact on rubber development.

Rubber estates as well as Bogor botanic garden research station began their own research programs in the 1920's leading to the release of clonal improved planting material after the 1930's based on grafting technique (in particular the famous GT1) [12]. The introduction of clones since that was most important in terms of yield and the main productivity improvement factor. Meanwhile, farmers developed several other no-cost "endogenous innovations", such as planting in lines and minimal weeding (once a year) mainly through the improvement of some rubber farming practices [18, 19]. At this stage, the aim was clearly for most smallholders to establish rubber systems which minimized capital and labor investment, and farmers made a perceptible shift from a "fallow enriched with rubber" towards a more genuine "complex rubber agroforestry system". The productivity of jungle rubber was low (500 kg/ha/year of rubber) compared to that of clones on estates (1500 to $1800 \mathrm{~kg} / \mathrm{ha} / \mathrm{year}$ ). After experimenting with endogenous innovations, farmers became more interested in also adopting such "external innovations" as clones, fertilization and good tapping systems [22]. Farmers began to have access to clonal rubber in monocultures through projects in the 1970's: mainly SRDP, TCSDP and NES projects (1970-2000) ${ }^{1}$ [7]. They also began to develop additional innovations such as inter-cropping during the immature period and planting perennials (or from natural regeneration) such as fruit and timber trees. They thus created an "improved rubber-based complex agroforestry system" where the original aim of improving the fallow disappeared in favor of the desire to establish a more productive cropping system $[28,20]$. Population increases, land scarcity in some areas, and introduction of other more

\footnotetext{
${ }^{1}$ SRDP $=$ Smallholder Rubber Development Project funded by the World bank, TCSDP $=$ Tree Crop Smallholder Development Project, Funded by ADB and NES = Nucleus Estates Schemes linked with the network of governmental Estates (PPT) with various funding.
} 
remunerative cropping opportunities combined to force farmers to evolve into a more productive Rubber Agroforestry System (RAS). Current agroforestry research (from 1994 to now) focuses on the potential to integrate indigenous knowledge related to jungle rubber with external innovations that will improve productivity while still conserving environmental and biodiversity benefits offered by traditional agroforestry practices [26, 5].

Rubber has proved to be adapted to meet the challenge with rice particularly in the rainy season. This is an Important feature because labor is the main available factor of production in the lack of any capital when land is still plentiful. So, from the beginning, rubber and ladang rice could merge with flexibility in existing farming systems. Meanwhile it has enabled migrants to settle down in these areas in increasing number therefore triggering the change in population density and pressure on available resources. Average population density in Sumatra is now 35 inhabitants $/ \mathrm{km}^{2}$ and land is becoming scarce in some provinces (North and South Sumatra, Lampung). According to [13], "the comparative ecology and economy of rubber and upland swidden rice result in minimal competition in the use of land and labor, and even in mutual enhancement, between the two systems". Jungle rubber and shifting cultivation are not at all antinomic as the two systems can coexist in local farming systems. The notion of "composite system" has been developed by [13].

It is clear that rubber has also triggered deforestation [37] and that timber concessions, with the example of South-Sumatra, has less impact on forest cover than any other land uses [26]. The paradox lies in the fact that now jungle rubber is the main reservoir of biodiversity [11]. and that rubber agroforestry systems are among the best adapted systems for maintaining a certain level of biodiversity compared to other land use system using oil palm, coconut, coffee, cocoa or pulp trees. Rubber has proved to be very adaptable to this "new" environment, compared to that of estates as, in both cases, The cost advantage of "smallholder versus estates" to establish a rubber plantation has been assessed as 13 to 1 during the colonial area [13], 6 to 1 related to estates in 1982 and between 3 to 1 and 11 to 1 related to governmental rubber schemes (Barlow et al, 1982), showing that there were very competitive cost advantages for rubber. Such a system has been well described $[15,11]$ and defined, from a botanical point of view, as a "complex agroforestry system".

A big advantage of jungle rubber (or further clonal RAS) is biodiversity conservation as biodiversity is close to that of primary forest or old secondary forest for a mature old jungle rubber [11,41] and environmental benefits in terms of soil conservation [38] and water management due to its forest-like characteristic. Bio-mass of a rubber plantation at 33 years old (445 t/ha dry weight) is similar to that of humid tropical evergreen forest in Brazil (473 t/ha [42, 40] or in Malaysia (475-664 t/ha) [42]. The constraints of jungle rubber have also been well identified (Gouyon, 1995/11): i) a delay in production of the rubber trees which are being tapped after 9 to 15 years after planting compared to those in estates, in monoculture system, which are tapped after 5 or 6 years after planting, and ii) a relatively low productivity (compared to plantations planted with clones). In 2021, jungle rubber system is economically clearly obsolete and is disappearing to the profit of oil palm or clonal rubber plantations. The future in terms of agroforestry is not anymore in jungle rubber system but in RAS cropping systems. From the 3 million ha of jungle rubber in 1993, there is probably only 1 or 1.5 million ha only left in 2019 replaced by oil palm and clonal rubber. The BPS official Indonesian statistics on rubber are not precised enough to know exactly the current distribution on rubber areas between jungle rubber, RAS and seedling or clonal rubber monoculture.

The normal evolution in terms of productivity was a move from jungle rubber based farming systems to clonal rubber partly implemented in the last 30 years. The second evolution has been the rapid development of oil palm and integration of that crop in current existing farming systems since the 2000's. Therefore, the main problematic is now to understand what happen to agroforestry practices and what remain from them in 2020 from 
both jungle rubber and RAS. Most jungle rubber has disappeared. Some farmers with no access to clones have also planted seedling in monoculture. We do not know today about RAS. It is time to replant old NES/SRDP/TCSDP plantations and we do not know it will be in monoculture or in agroforestry pattern.

\subsubsection{Impact of oil palm development in the area}

In 1994-1996, during trials' establishment, the oil palm area in the regions under study was close to zero. In 2019, the situation is fundamentally different and the land use distribution is now as follows for the Kabutaten Sanggau where SRAP trials are located:

1. Hutan lindung/protected forest: 100,221 ha

2. Hutan produksi/potential forest to be converted: 453,300 ha

3. Land for plantation: 723,000 ha

4. Land covered with rubber: $\mathbf{1 0 7 , 0 0 0}$ ha $(\mathbf{5 2 , 3 0 0}$ families $)=\mathbf{2 8 \%}$

5. Land covered with oil palm (both estates and smallholders): 283,500 ha, $\mathbf{7 2} \%$ (58,900 families)

(Source: BPS, 2020)

Oil palm was booming from 1997 to 2010 [14]. Oil palm is now the very first crop for local farmers in the area (72\% of the cropped area) and estates, even if rubber remains important for local farmers who want to maintain a certain level of crop diversification. We found that most of the jungle rubber area (that covered $90 \%$ of the rubber area in 1994) has been converted to oil palm and/or clonal rubber plantation to a lesser extent. In other words, the majority of jungle rubber has currently disappeared although rubber production is maintained, because clonal rubber yields 3 times more than jungle rubber. Oil palm has been like a «steamroller » in the landscapes under study. Indeed, most local Dayak farmers have exchanged their land at the benefit of oil palm estates ( 5 ha lost for 2 ha planted provided by the estate to the farmer). Now, most farmers cultivate in average 2 ha of oil palm, 2 ha of rubber (partly clonal and sometime remaining jungle rubber) and a small area for food crops or other crops. These farmers cannot count anymore on land availability as they did some 25 years ago. We do not know exactly what is the proportion of clonal rubber which is currently cultivated as agroforestry: this might reach more than $30 \%$.

It is important to understand the pros and cons of oil palm and how oil palm has significantly changed land use, local farmers' strategies and cropping patterns. The « pros » for oil palm are: i) low labor requirements: 8 days a month/ha compared to 14 for rubber, ii) secured incomes up to now despite fluctuations, iii) access to homes and some social benefits, iv) new roads and access to markets and v) Oil palm provides regular and secure incomes.

The « cons » are: i) Loss of land according to concessions regulations (5.5 ha), ii) risk of monoculture: less resilience, iii) requires an investment of 700/1000 kg of fertilizers/year/ha and the corresponding capital availability, and iv) recent decrease in fresh fruit bunches (FFB) price.

Consequently, for local smallholders, oil palm is now the number one crop, as jungle rubber has almost disappeared and clonal rubber is still cultivated, partly under agroforestry. Some local Dayak farmers also maintained some jungle rubber as a land reserve while preserving tembawang (man-made agroforests with fruits and timber trees under shared social regulation called « adat»). We were able to estimate that in the area of study (in the 4 villages where SRAP has been developed ) $70 \%$ of available land was under oil palm, $20 \%$ under clonal rubber (monoculture or agroforestry systems ) and $10 \%$ remained as old jungle rubber and tembawang, according to farmers' opinion. In transmigration areas, the situation is different, as most farmers own only 2 ha (sometimes 3 ha) mainly planted with clonal rubber. Oil palm companies did not intend to penetrate these areas with a special status 
however they are generally surrounding transmigration schemes. These farmers do not have any possibility to cultivate oil palm on new land [32].

\subsubsection{Impact of current low rubber price (since 2013)}

It is quite clear that the long period of low rubber price which occurred since 2013/2014 (see figure 8) did not help in favoring clonal rubber plantation, in particular for young generations. However, old farmers remain convinced of keeping both crops (rubber and oil palm) in their production systems. The situation in 2015/2021 is very similar to that of 1998/2006 with low rubber prices and significatively negative impact on income $[29,36]$.

Meantime, oil palm has been remarkable stable since 1997 leading to a real trust of farmers in oil palm source of income. But one main advantage of rubber was the very low input cost (compared to the necessity to fund 1 ton of fertilizers/ha/year for oil palm) and the possibility to rely entirely on family labor with no cost for production.

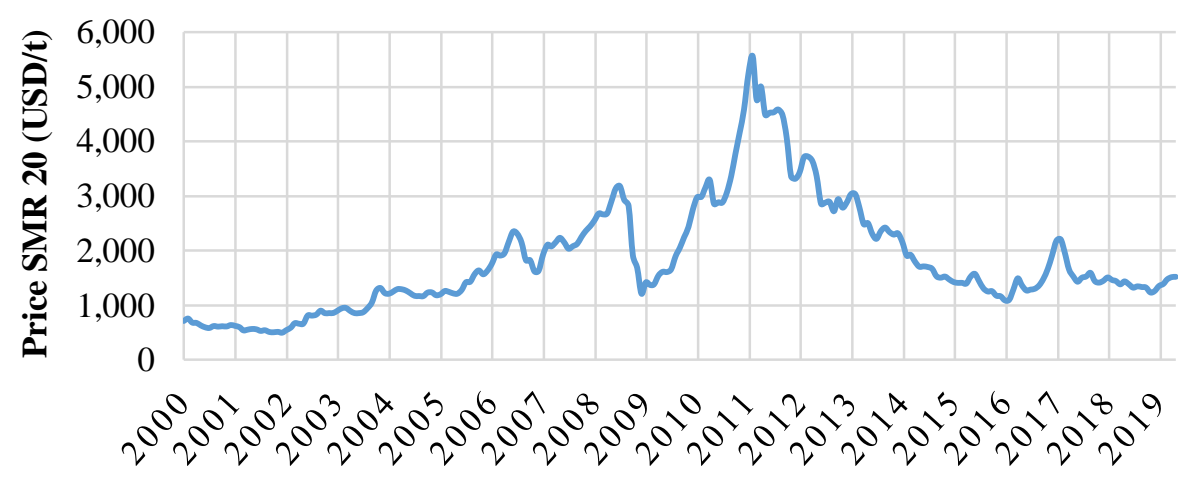

Fig. 1. Price of Natural Rubber (Grade SMR20) in Kuala Lumpur from January 2000 to May 2019 (Malaysian Rubber Board, 2019)

\section{Material and methods}

\subsection{History of SRAP, an ICRAF/CIRAD research project (Smallholder Rubber Agroforestry Project) : the set-up of RAS on-farm-trials.}

In 1994, ICRAF and CIRAD jointly launched the SRAP-Smallholder Rubber Agroforestry Project in order to set up several on-farm trials based on agroforestry systems in the Indonesian provinces of West Kalimantan, Jambi and West Sumatra [34]. These trials followed three different designs, namely: i) RAS1 which involved clonal rubber plantation and forest regrowth in the interline (the most extensive system), ii) RAS 2 in which clonal rubber was associated with fruit and timber trees and intercropping during the immature period (the most intensive system), and iii) RAS 3 which was planted under the same design as RAS 2 but complemented with fast growing shading trees and the use of a cover crop (mainly Flemingia congesta) to get rid of alang-alang (Imperata cylindrica) in invaded plots [29]. The main idea was to assess if the different combinations of associated trees and crops with clonal rubber had any long-term impact in term of income diversification and agroforestry practices adoption. In SRDP plots in the village of Sanjan [23] where local farmers did implement before 1994 what became ultimately the RAS 2 type agroforestry (figure 1), $25 \%$ of SRD farmers of these village did implement agroforestry plots with success with mostly fruit production and very few timber production [39]. The SRDP AF 
plots in Sanjan show us that agroforestry practices was possible without significant decrease of rubber production (the main economic output). Therefore, the idea through SRAP was to test several tree combinations to provide a wide range of technical solutions. The main problems were the following: i) to verify that AF effectively did not impact rubber production and in which conditions and did not impact rubber growth as well during immature period in order to tap the trees as soon as possible after planting (generally between 5 to 7 years) and ii) identify the best tree/other plants combinations to fulfil the expected results: for instance in terms of competition with Imperata Cylindrica etc

Each trial was replicated in 2 or 3 villages with a minimum of 7 replications/farms ( 7 to 10) for each trial with the same design (planting density, tree association and practices) on the same type of soil and climate. Each trial comprised 6 to 8 sub-plots with a different treatment (i.e. type of clone, type of fast growing associated trees, type of intercrops, type of cover crop, etc). All trials have been managed by farmers using the same agronomic practices, which were decided before planting [5]. The total number of trials plot/farmers was 60 in West Kalimantan, planted in 2 main zones, namely: i) Dayak smallholding (mainly after jungle rubber) in local traditional zones and Malayu farmers in transmigration ${ }^{2}$ areas (with some presence of Imperata cylindrica) trough program or relocation of people from Java.

\section{SRAP ICRAF/CIRAD on farm trials location in West kalimantan: Sanggau and Sintang area}

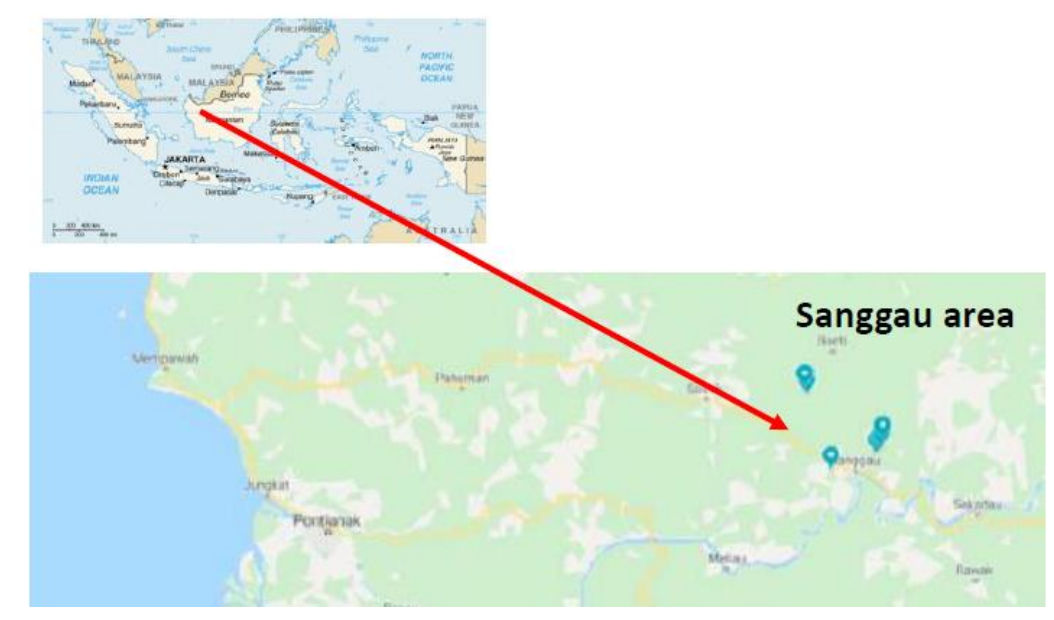

Fig. 2. SRAP study areas in West-Kalimantan

\footnotetext{
2 Transmigration was a program of the Indonesian government to resettle population from Java to the less populated areas of Indonesia (known as the "periphery"), mainly to Kalimantan, Sumatra, Sulawesi, Maluku and West Papua (Irian Jaya).
} 


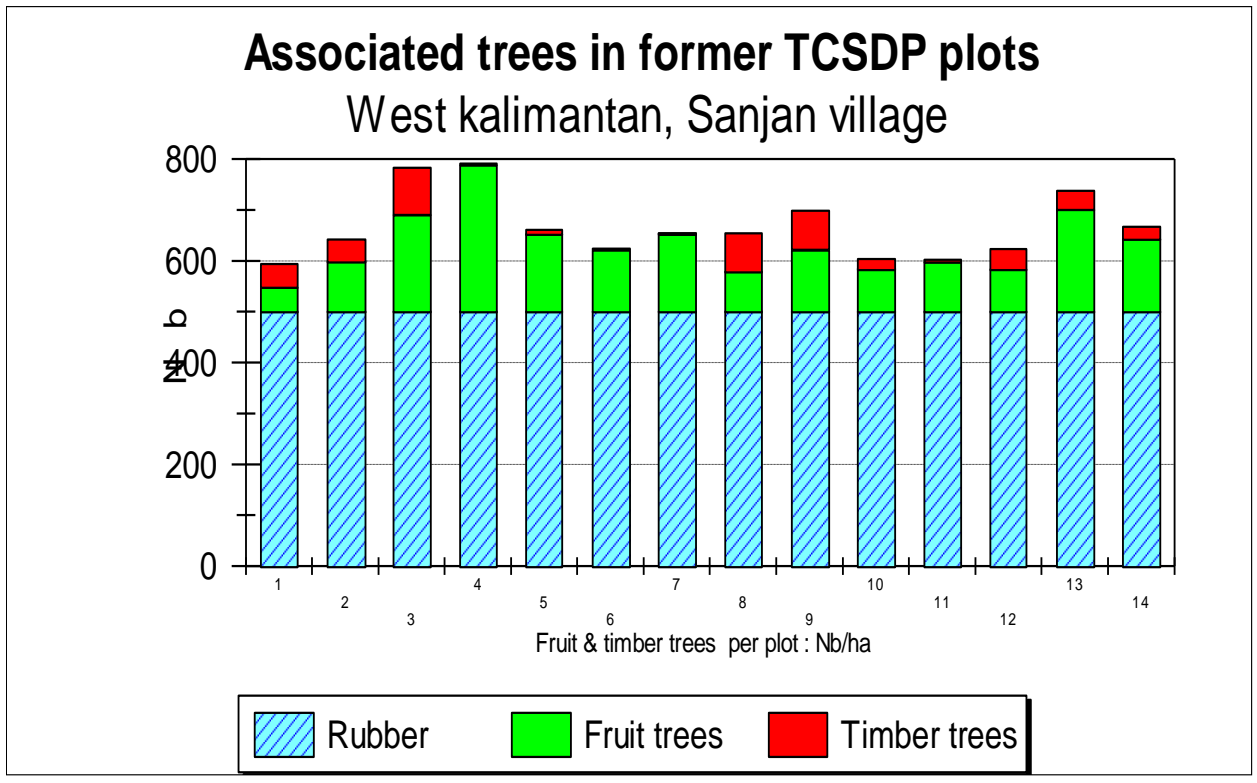

Fig. 3. Associated trees in former Sanjan SRDP clonal rubber plots (planted in the 1980's) that lead to RAS 2 type in 1994.

A first series of trials was established in 1994-1996 in the villages of Kopar, Engkayu, Embaong, Trimulia (Sanggau area) and Pariban baru (Sintang area). A second series was established between 2000 and 2005 in Pana (Sanggau area). The main outcomes which were expected from clonal rubber-based agroforestry systems were as follows:

1. Income diversification (rubber, fruits, timber) = better economic resilience,

2. No impact of agroforestry practices on rubber production, as long as there are no trees above rubber canopy,

3. Reservoir of local biodiversity and « forest effect » on local climate, if widely used, for a better global resilience. The expected forest effect is multiple as well: i) maintain or improve Carbon stock, ii) maintain humidity, iii) rainfall patterns, and iv) access to "forest products".

4. Less soil erosion and better use of water,

5. Soil fertility maintenance or improvement, if soil surface is covered,

6. Possibility of timber production: rubber farmers might be the very next timber producers,

7. A more environmentally friendly system in a broad sense

8. Rubber production does not require fertilizers nor pesticides: it is thus already « bio compatible », i.e. for instance for organic farming intercropping. 

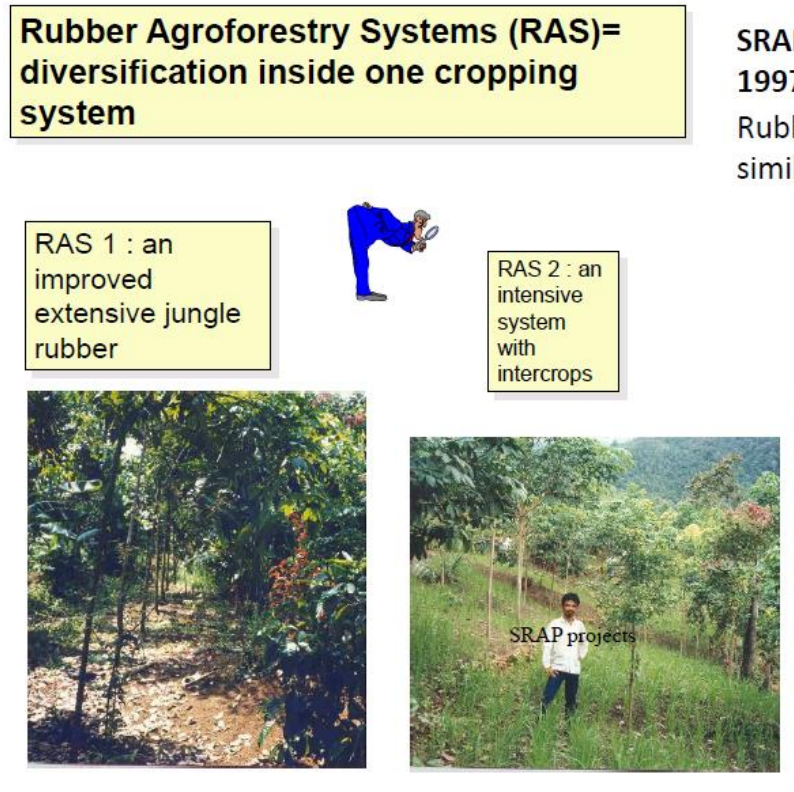

1994 to 2007
SRAP research programme 1997/2007

Rubber planting density similar to that of monoculture

Fig. 4. Short synthetic description of the 3 RAS systems

The 3 RAS systems are described in the following figures (5, 6 and 7). 


\section{RAS 1: a productive jungle rubber}

Jungle Rubber is a very rich
habitat and a reserve of
biodiversity. The ecological
niche is at danger because of
the low productivity of the
system (rubber yields in a
range of $300-400$ kg of dry
rubber and, generated
income is insufficient
because of low productivity.
As farmers have more
profitable alternatives like:
oil palm, coffee, or
cinnamon, the jungle rubber
environment is at risk.
SRAP (Smallholder Rubber
Agroforestry Project)
developed strategies to
conserve jungle rubber
environment with an
increased productivity.
The use of high yielding
clones in RAS 1 ensures a
good potential for rubber
production.
The promotion of natural
vegetation re-growth permits
the return of local bio-
diversity
The system is particularly
attractive to farmers thanks
to low input technology and
minimum labor needed.

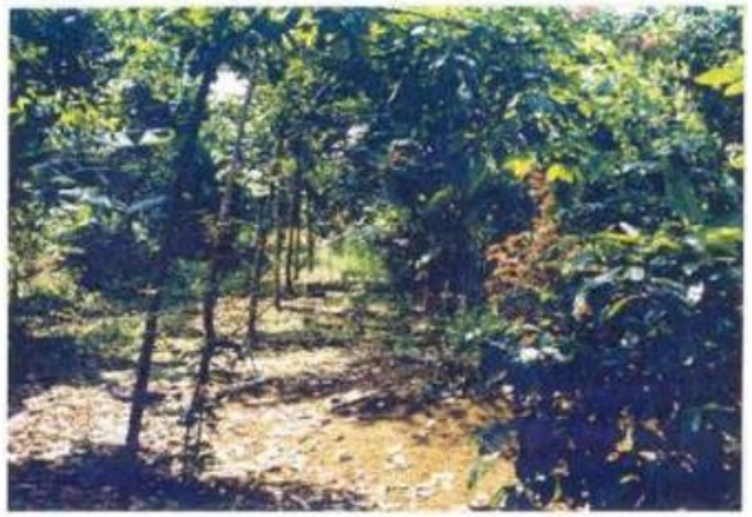

\section{RAS 1 Environment.}

The natural vegetation re-growth is promoted by maintaining favorable conditions for rubber growth: soil moisture and control of noxious weeds like Imperata cylindrica

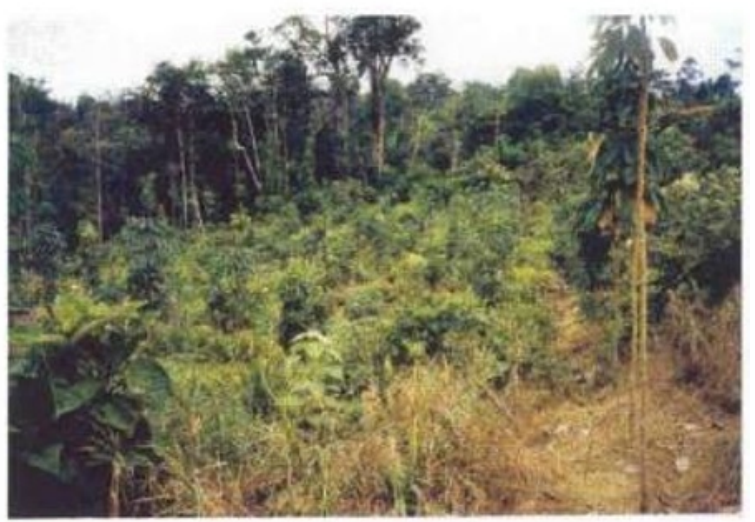

Technology package for RAS 1 implementation

- Planting of clonal plants raised in polybags

- Weeding every 3 months on the rubber row only

-Limited inputs: Rock Phosphate and Urea applied during the two first years

Fig. 5. the RAS 1 cropping system 


\section{RAS 2: a complex agroforestry system}

\section{Rubber maintained by smallholders is rarely conducted in monoculture. \\ At early stages, rubber is intercropped with upland rice then, with various food crops (palawija).}

Farmers often plant some fruit and medicinal trees optimizing the available land.

In West-Kalimantan, old rubber groves mutate into a "tembawang": a fruit orchard with rubber, fruit and timber trees.

RAS 2 uses strategies already adopted and implemented by smallholders in their holdings.

The innovations introduced in RAS 2 focus on:

- the use of high yielding rubber clones

- a judicious choice of crops and tree associations, in accordance to farmers' desires.

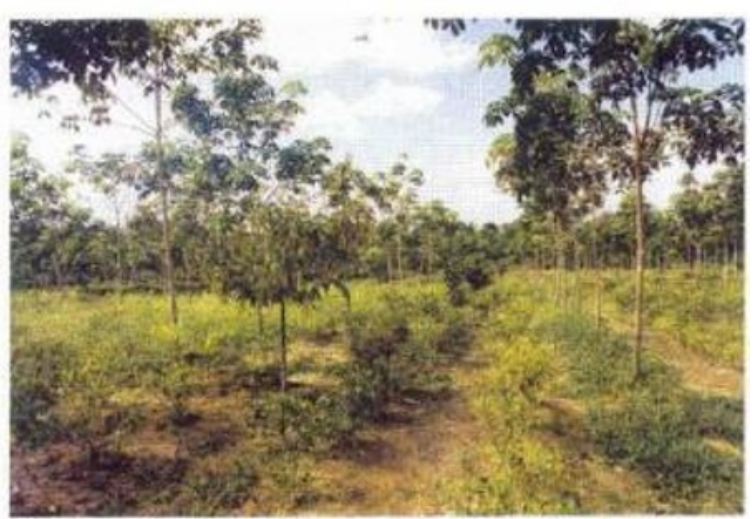

RAS 2: a complex agroforestry system.

Fruit trees are planted between rubber rows.

Annual crops are grown in the inter-row. After two crops of upland rice, other crops like: chilies, com and cassava are often cultivated.

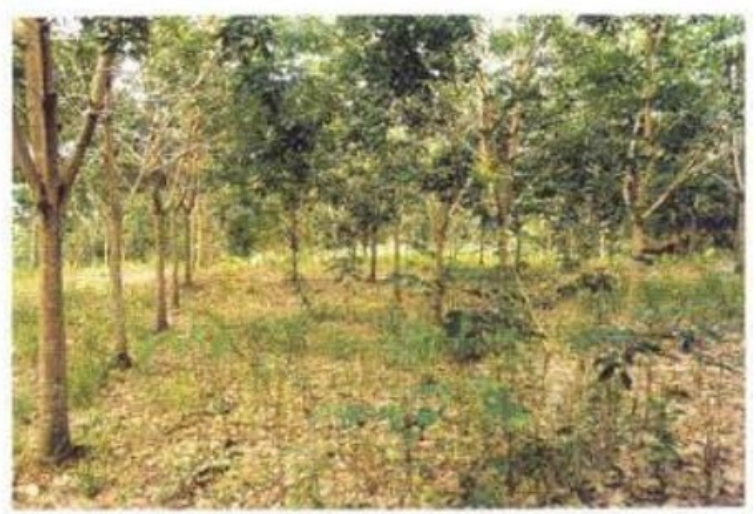

Technology package for RAS 2 implementation

- Planting clonal plants raised in polybags

-Weeding every 3 months on the rubber row

-Limited inputs Rock Phosphate and Urea applied during the two first years

- regular weeding of associated crops

Fig. 6. The RAS 2 cropping system 


\section{RAS 3: How to develop Imperata grasslands?}

\begin{tabular}{l} 
The rehabilitation of Imperata \\
grasslands needs large \\
investment often out of the \\
reach of farmers. Using RAS 3 \\
technology, farmers can \\
rehabilitate Imperata \\
grasslands at acceptable cost. \\
RAS 3 uses legume cover \\
crops, shrubs or fast growing \\
trees (FGT) to control \\
Imperata cylindrica by \\
shading. \\
As land infestation by \\
Imperata is rapid, various \\
species were selected for their \\
ability to grow fast, even in \\
adverse conditions and to \\
compete with Imperata. \\
Cover plants under test are: \\
- CC: Pueraria javanica, \\
Mucuna utilis, Setaria \\
macrotachia \\
-Shrubs: Flemingia congesta, \\
Chromolaena odorata, \\
Crotalaria anagyroides \\
-FGT: Paraserientes falcata, \\
Gmelina arborea, Acacia \\
mangium \\
\hline
\end{tabular}

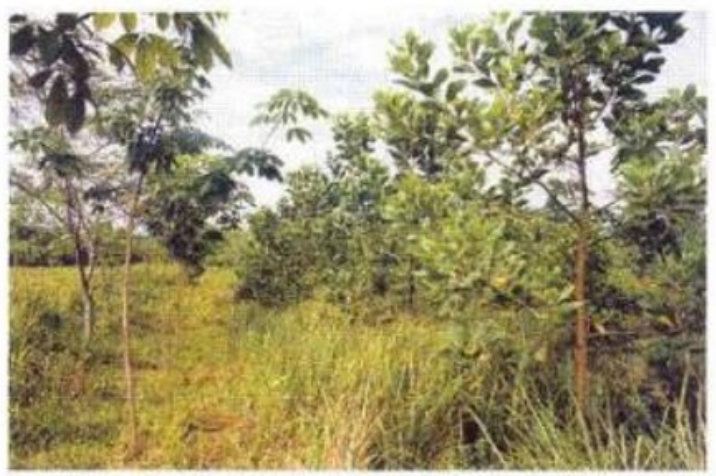

\section{RAS 3 : a complex agroforestry system.}

Shrubs, cover crops or fast growing trees (FGT) are planted in rubber inter-row to control Imperata cylindrica by shading.

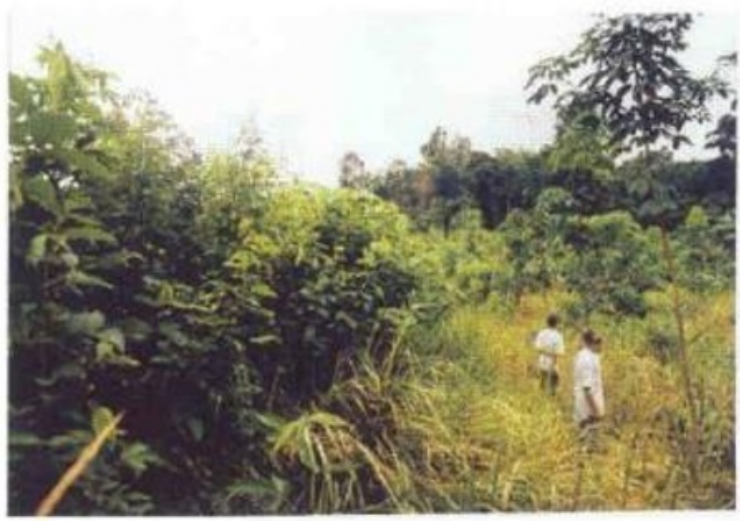

\section{Technology package for RAS 3 implementation}

- Planting clonal plants raised in polybags

-Weeding every 3 months on rubber row

- Limited inputs Rock Phosphate and Urea applied during the two first years

-Promotion of cover crops, FGT, and shrubs to control Imperata cylindrica

Fig.7. The RAS 3 cropping system 


\subsection{Economic rationale}

An economic comparison of the various systems (figure 7) with ancient and recent jungle rubber, poor/good oil palm plantation and monoculture/RAS systems shows -for the year 2000 (very similar to that of 2020)- that clonal rubber-based systems provide a good level of income compared to any other per hectare (in particular rice or "palawija" or other upland secondary annual crop (soybean, maîs, peanut etc), usually on a longer lifespan than oil palm if tapping practices are correct (35 years for rubber when it is 20 years for oil palm. The situation is more or less similar in 2019, according to local farmers' statement but further indepth research is definitely needed to corroborate that perception. The rubber income and perception of rubber interest is of course heavily linked with rubber prices. In the last 30 years, we had in alternance periods of high price (up to 5 US $\$ / \mathrm{kg}$ in 2011 and periods of low price (0.5 US\$/kg in 1999 or currently $1.3 \mathrm{US} \$ / \mathrm{kg}$ in 2019).

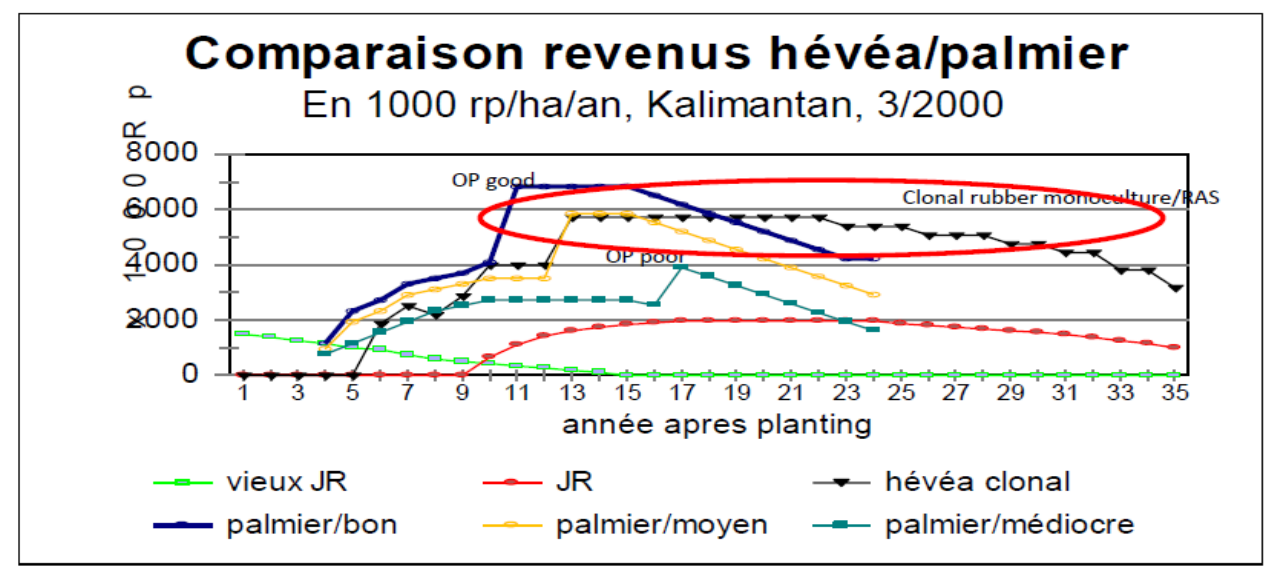

Fig. 8. Income comparison for various types of tree cropping systems in 2000 (Oil palm, rubber monoculture and RAS, jungle rubber)

In fact, depending on respective oil palm and rubber market prices, income from both crops were very similar and complementary in terms of labor. Further studies have been published with farming system modelling and income analysis [16, 30, 33].

\subsection{The survey in 2019}

A survey has been implemented in October 2019 with the following items: i) visits of all former RAP on-farm-trials plots and ii) a discussion trough focus group approach with all SRAP farmers.

\section{Results and discussion}

\subsection{Changes in RAS systems: the evolution from 1994 to 2019}

RAS 1 was found to perform as best for soil fertility maintenance, no erosion and low cost of establishment for immature period, either in 1997 and 2007 during survey implemented at these periods as now in the long run by farmers that did maintain their RAS plots (more than $80 \%$ ). This is interesting for most smallholders who are reluctant to invest $2,000 \mathrm{US} \$ /$ ha for new clonal rubber plantation from their own savings (compared to plantation done by local 
estates for oil palm with a dedicated credit). Establishment cost and maintenance for the first 3 years were estimated in 1997 at 700 US\$/ha [4].

RAS 2 is the most widely adopted type, due to the production of associated trees (both fruits and timber recently) despite the fact that poor markets for fruits and timber are real constraints for further development (see pictures 3 and 4)

RAS 3 "did the job" in alang-alang (Imperata cylindrica) infested environments, with a very good control through the shading provided by associated trees and cover crop (Flemingia congesta). Such results were obtained without Roundup in transmigration areas and in some villages like Pana (see picture 5) [4].

Changes in various trials plot were recorded and they showed the following trend:

1. Conversion to oil palm (20\% of SRAP plots) or to clonal rubber monoculture $(20 \%$ of SRAP plots mainly in Trimulia), with agroforestry systems maintained in RAS 1 or 2 (50\% of the SRAP plots) and tembawang (10\% of the SRAP plots).

2. In Trimulia village (transmigration area): $100 \%$ of rubber plots are now in monoculture due to poor sandy soils, lack of water for associated trees and priority given to rubber trees.

3. In Kopar: $80 \%$ of rubber plots are in RAS $1(50 \%)$ as shown in picture 2 and RAS $2(50 \%)$ see picture 1 where access to forest products remain important for local population.

4. Engkayu : $60 \%$ of rubber plots are in RAS 2 where global productivity through fruit production is important to maintain agricultural income.

5. Embaong : $30 \%$ of rubber plots are in RAS 2, the rest between RAS1 and monoculture

6. Pana: $90 \%$ of rubber plots are in RAS 2

7. Sanjan (former SRDP and no SRAP trials): $50 \%$ of the area remains under clonal rubber and $1 / 4$ of the rubber plantation is in agroforestry.

8. And some plots were changed into tembawang a local fruit/timber based agroforest (less than $10 \%$ )

\section{RAS1 evolution in Kopar into a RAS 2 (Indi)}
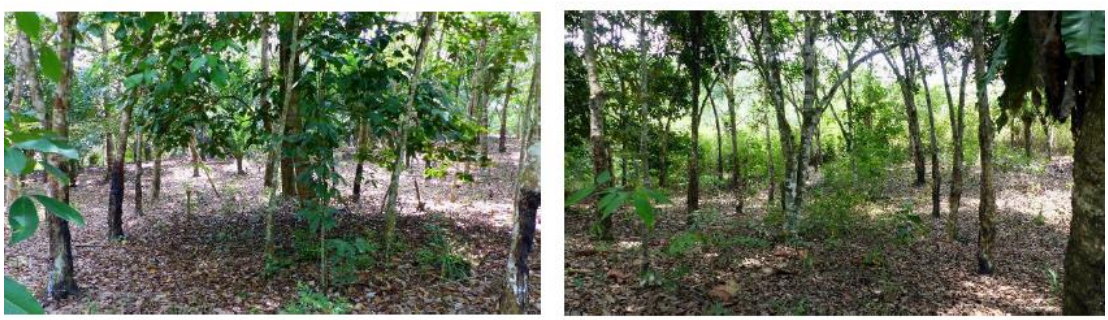

Rubber associated with Pegawai, durian, jackfruit mango, Tekam
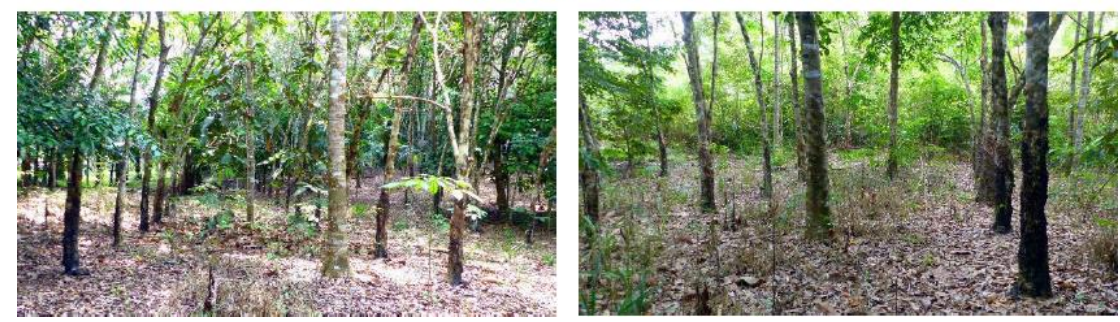

Fig. 9. Example of RAS1/RAS 2 evolution 


\section{RAS1 remains a RAS 1 Kopar (Jampi)}
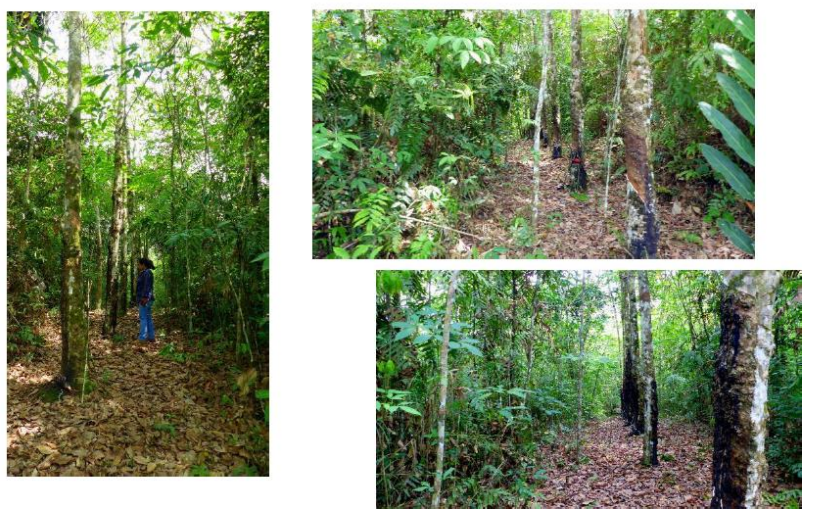

Fig. 10. Original RAS 1 remaining as RAS 1

\section{RAS 2: the main locally recommended by local farmers}

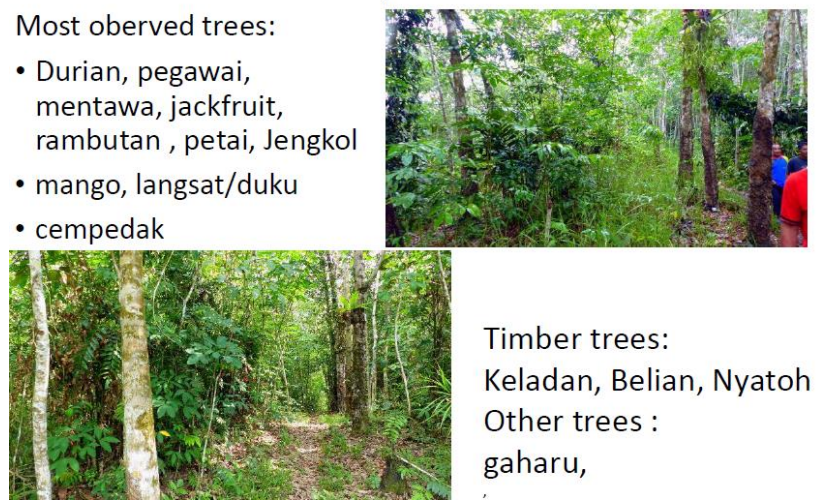

Fig. 11. RAS 2 types with fruit and timber trees (between 100 to 250 /ha)

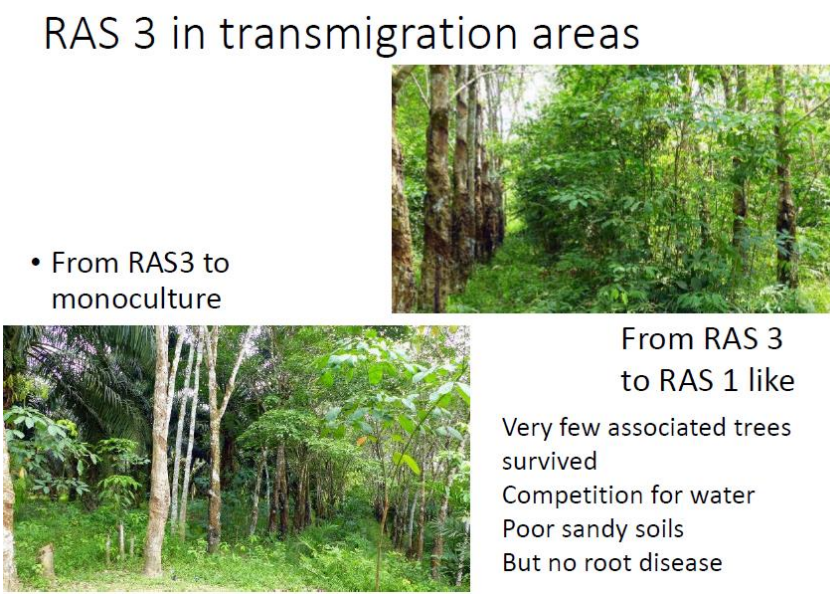

Fig. 12. RAS 3 type as a successfull anti Imperata cylindrica strategy 


\subsection{Comparison between 1994/1997 establishment period and the current situation}

Most trials have been established between 1994 and 1996 in the villages of Kopar, Engkayu, Embaong, Trimulia, Pana (Sangau area) and Pariban baru (Sintang area). Another set of trials plots have been planted between 2000 and 2005 in the village of Pana. Trials plots have been regularly visited between 1994 and 2007. ICRAF ended up the trials monitoring at the end of 2007 with the completion of CFC funding. The pictures show the situation in 1994/1997, then in 2005/2007 and eventually in 2019 .

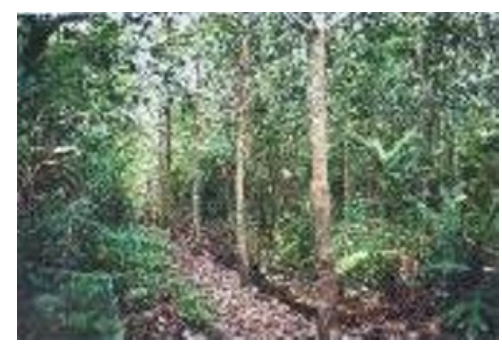

RAS 1 plot in 1997 (3 years old in Engkayu)

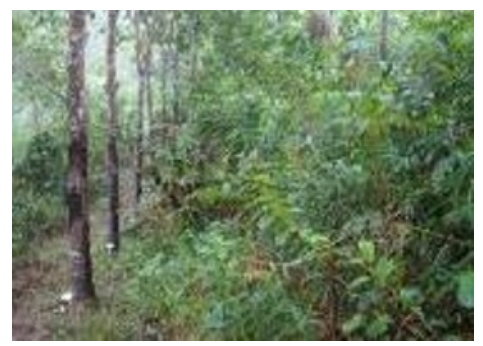

RAS 1 plot in 2005 (8 years old) in Embaong

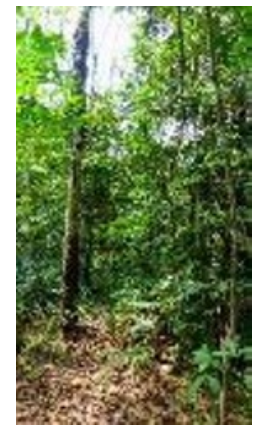

RAS 1 plot in 2019 (22 years old) in Engkayu)

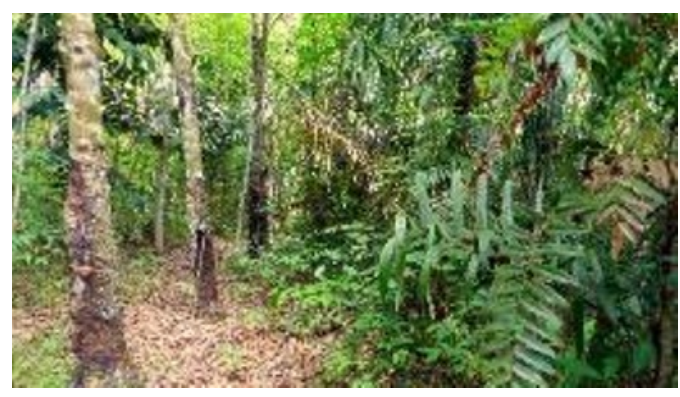

RAS 1 plot in 2019 (22 years old) in Engkayu)

Fig. 13. RAS 1 evolution

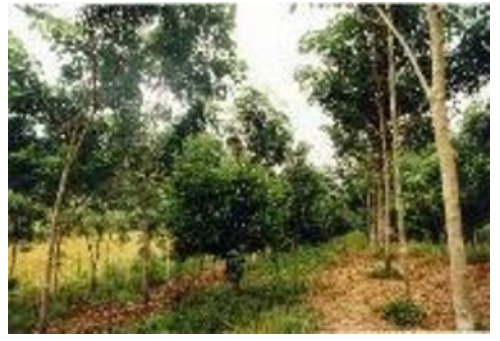

RAS 2 plot in 1997 ( 3 years old in Engkayu)

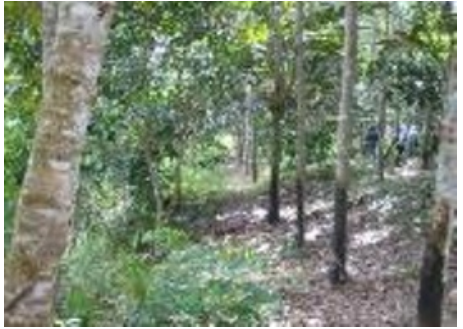

RAS 2 plot in 1997 (3 years old in Kopar 


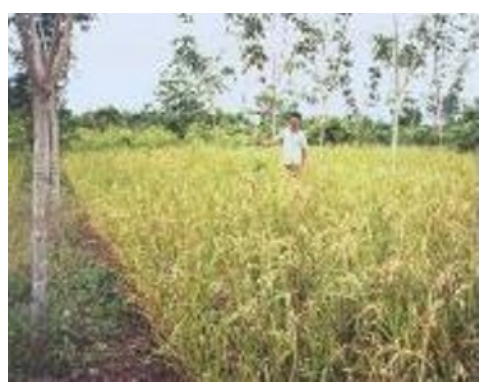

RAS 2 plot in 1997 (3 years old in Trimulia with rice

Fig. 14. RAS 2 evolution

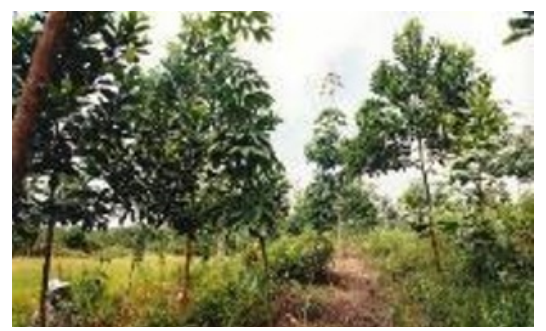

RAS 3 plot in 1997 (3 years old in Trimulia with Acacia mangium and Flemingia congesta for shadowing and associated fruit trees

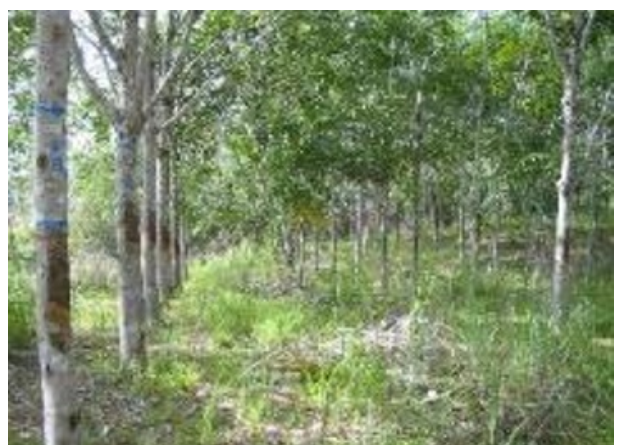

RAS 3 plot in 2005 (8 years old) in Trimulia in monoculture

Fig. 15. RAS 3 evolution

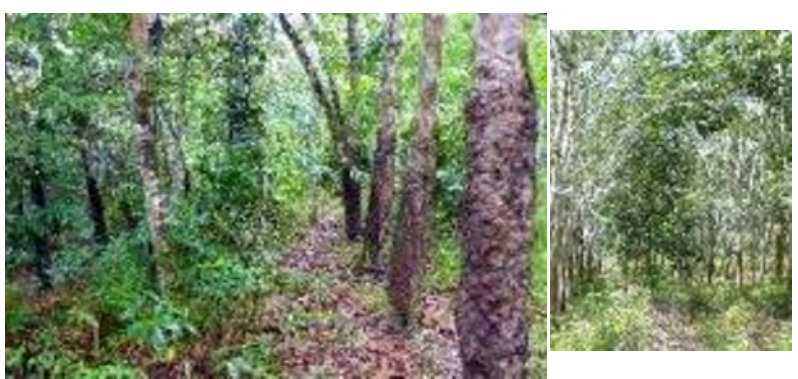

RAS 2 plot in 2019 (22 years old) in Trimulia with associated fruit trees

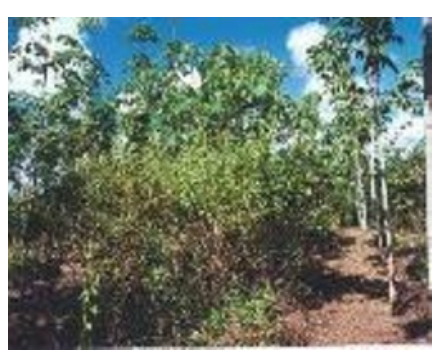

RAS 3 plot in 1997 (3 years old in Trimulia with Gmelina arborea and Flemingia congesta for shadowing and associated fruit trees

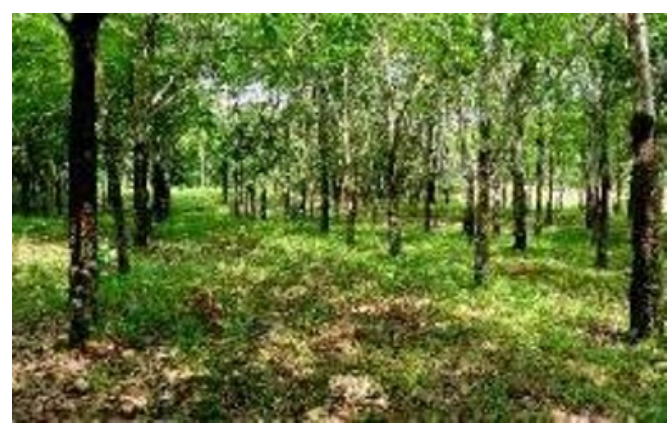

RAS 3 plot in 2019 (22 years old) in Trimulia in monoculture 


\subsection{Evolution in agronomic practices: tapping practices and diseases}

The main problem affecting rubber production is the very poor quality of tapping practices. Indeed, in $\mathrm{SRDP}^{3}$ plot with a clone selection based on GT1, it is clearly observed the effect of initial training on tapping and D2 frequency (tapping every 2 days). The lifespan of trees is 35 years in Sanjan and Embaong villages were SRDP was developed at the end of the 1980's. SRAP introduced the possibility to diversify access to good clones, with the following selection of genotypes: BPM1/24, 24, RRIC 100, RRIM 600 and PB 260. Unfortunately, insufficient training on tapping practices at the time of tree opening (between 2002 and 2004) and high tapping frequency (in particular when rubber prices were low and tapping was performed everyday) significantly reduces the lifespan of rubber trees down to 20-25 years in trial plots. The second problem acknowledged during the present mission was the impressive impact of Fomes/White Root disease and obviously another root disease (so far unknown or not identified) on rubber trees during their whole lifetime, in particular in areas where trials were established after secondary forest or old jungle rubber, with a very high amount of root biomass remaining in soils. Some trials have been severely impacted, with more than $50 \%$ of trees destroyed in the last 4 years. Their final decision therefore is to replant in the very next future the plot most generally with clonal rubber.

Do agroforestry practices increase risks of Fomes and other root diseases? So far, it seems that there is no difference in susceptibility to fungal attacks between monoculture and agroforestry systems. The main factor is the precedent crop or land use before planting (Embaong/rich soils/old jungle rubber). For instance, there is no such impact on soils initially covered by Imperata cylindrica (Trimulia/sandy soils/alang alang).

\section{Conclusion}

Today, all forest and most jungle rubber have disappeared to the profit of roughly $2 / 3$ of the area with oil palm and 1/3 with clonal rubber, either in monoculture or agroforestry.

In the region under study, the major change in land use and farmers' strategies has been clearly the rapid and significant development of oil palm which quickly became the priority number one for local smallholders. In the meantime, local estates took over most of the available land for their own oil palm plantations. Meanwhile, low rubber price hampered any interest in rubber cultivation. Despite this situation, smallholders did not want to abandon rubber definitively. Rubber is still planted, as it provides a better use of available family labor, in complement of that used for oil palm production and income diversification (monoculture and RAS 2 mainly).

We are back to the same problems and same situation that we faced in 1994: poor access to clonal planting material, no training on tapping frequency and practices but with some knowledge on clones and AF practices. It seems that there is no transmission of rubber cultivation techniques to young farmers and sons.

All trials are at the end of their lifespan, which was reduced down to 20-25 years due to diseases and poor tapping practices. Agroforestry practices have been considered as very interesting for most farmers: i) during the immature period of rubber trees, for a better valorization of land with intercrops or reduced costs of establishment depending on the type of RAS and 2) income diversification (either for self-consumption or marketing, for some fruits and timber) and improved farm resilience and less dependency to commodity price volatility.

The lessons learned are the following : i) Rubber agroforestry trials came right in time in 1994, with a strong demand from farmers for systems providing low establishment cost and

${ }^{3}$ SRDP for Smallholder Rubber Development Project funded by the world bank from 1990 to 2000) 
income diversification: the right time at the place, ii) but oil palm came in 1997 with a very strong pressure from companies (through the policy of concessions) providing a lucrative alternative to rubber cultivation with full credit (but loss of land) and better return to labor, iii) Interest in agroforestry practices remains high for old men but no interest is witnessed from younger generation, iv) It is now time for rubber replanting as trees are old, and the same old story remains (access to planting material), v) Good tapping practices (tapping school and training, technical information on panel management, upward tapping) are essential to be able to maximize tree lifespan up to 35 years long, vi) Important impact of white root and other root diseases in areas with forest or old jungle rubber before plantation and vii) Low rubber prices especially compared to palm oil do not help in maintaining farmers' interest in rubber cultivation.Most trial plots are now at the end of their life, due to the high impact of diseases and poor tapping practices.

It would be very interesting to do an in-depth socio-economic survey involving all SRAP farmers in order to assess the current situation of farmers' income (from oil palm/rubber and any other sources), and their ongoing and planned strategies and to explore the reasons governing their present interest in clonal rubber cultivation and agroforestry systems. An historical and prospective analysis could be performed to assess the impact of oil palm and rubber price volatility. This survey has been done in mid 2021.

Three major questions are clearly part of the research agenda:

1. What is the impact of fruit production from agroforestry systems on food security and diet quality of local families,

2. What is the impact of timber production, both for self-consumption in households and marketing,

3. To what extend such AF systems are able to provide better climatic resilience for both rubber and intercropped varieties?

Therefore the next steps would be: i) to Analyse the results of the socio-economic survey on all former SRAP farmers in particular income analysis to understand current strategies and evolution ii) A perception analysis on agroforestry practices as a mean to reduce rubber establishment cost and provide more income diversification at farm level (more resilience to price volatility), iii) a study on available markets for associated trees (Durian, Gaharu, Duku) and new emerging market for associated trees in RAS (Pekawai, Petai, Jengkol, timber trees).

The authors would like to thank ICRAF, IRRI, GAPKINDO, USAID, CFC and CIFOR/FTA for supporting and funding the original SRAP project and the 2019 mission. Thank you to Ir. Mme Ilahang from SNV as principal former SRAP/ICRAF investigator who has provided his valuable input and suggestions in writing this paper and accompany the author for the field visit.

\section{References}

1. Baudens, S. Etude bibliographique sur les aspects économiques de la biodiversité des SCAF à hévéa. Document interne CIRAD. Mémoire de seconde année de ISE, St Quentin en Yvelines, France: 35 pages (2000).

2. Beukema, H., M. van Noordwijk, et al. Biodiversity in rubber agroforests. SRAP Workshop on Rubber Agroforestry Systems in Indonesia, Bogor, Indonesia, 29-30 September 1997, Smallholder Rubber Agroforestry Project (1997).

3. Boutin, D., Penot E, Wibawa G. and Akiefnawati R. Rubber Agroforestry Systemstype 1 (RAS1): a strategy towards a productive "jungle rubber". IRRDB annual conference, Bogor, Indonesia, IRRDB (2000).

4. Boutin, D., Penot E. and Ilahang. Rubber Agroforestry Systems-type 3 (RAS 3), a strategy to convert Imperata grasslands. IRRDB annual conference, Bogor, Indonesia, IRRDB (2000). 
5. Boutin, D., Penot, E. Replantation des agroforêts à hévéa en Indonésie: Les systèmes agroforestiers améliorés à base de clones $(R A S)$; une alternative à la monoculture ? Conférence internationale "avenir des cultures pérennes : investissement et durabilité en zone tropicales humides"., Yamoussoukro, RCI, Novembre 2001, ICRAF/CIRAD (2001).

6. Budiman, A. F. S., Penot E., et al. RAS as alternatives for smallholder in Indonesia Integrated rubber agroforestry for the future of smallholder rubber in Indonesia. Conférence Nationale sur le caoutchouc, Medan (IDN), IRRI, Indonesia (1994).

7. Chambon, B. De l'innovation technique dans les sociétés paysannes : la diffusion de la monoculture clonale d'hévéa à Kalimantan Ouest (Indonésie). Thèse de doctorat. Facultés des Sciences Economiques de Montpellier 1. Montpellier, France (2001).

8. Chambon, B., Duangta, K., Promkhambut, A. \& Lesturgez G. Field latex production in Southern Thailand: a study on farmers' and traders ' practices that may affect the quality of natural rubber latex delivered to the factories. J Rubber Res. 23:125137(2020). https://doi.org/10.1007/s42464-020-00043-x

9. Courbet, P., Penot E. et al. Farming systems characterization and innovations adoption process in West Kalimantan. ICRAF/SRAP workshop on RAS (Rubber Agroforestry Systems), September 1997, Bogor (1997).

10. Diaz-Novelllon S., Penot E., Arnaud M. Characterisation of biodiversity in improved rubber agroforests in West-Kalimantan, Indonesia. Real and Potential uses for spontaneous plants. Land-use, nature conservation and the stability of rainforest margins in Southeast Asia. International Symposium, September 29October 3, Bogor, IndonesiaI/PB Bogor, University of Gottingen-University of Kassel (Germany) (2002).

11. De Foresta, H. Smallholder rubber plantations viewed through forest ecologist glasses. An example from South Sumatra. ICRAF/SRAP workshop on RAS (Rubber Agroforestry Systems), Bogor (1997).

12. Dijkman, M. J. Hevea. Thirty Years of Research in the Far East. Coral Gables, Florida, University of Miami Press.

13. Dove, M. (1993). Economic Botanic. 47,2 (1951).

14. Geissler, C., Penot E. "Mon palmier à huile contre ta forêt ".Déforestation et politiques de concessions chez les Dayaks, Ouest-Kalimantan, Indonésie. Bois et Forêts des tropiques. 2000 (1999).

15. Gouyon, A. Paysannerie et hévéaculture dans les plaines orientales de Sumatra : quel avenir pour un système agroforestier ?. Paris : INA-PG. 2:583 p.). Thèse de doctorat : Agro-économie : Institut national agronomique Paris-Grignon (1995).

16. Laxman J, Wibawa G, Ilahang, Akiefnawati R, Mulyoutami E, Wulandari, D and Penot E. Diversified rubber agroforestry for smallholder farmers : a better alternative to monoculture. Workshop on "Rubber Development in Lao PDR: Exploring Improved Systems for Smallholder Rubber Production”, Vientiane, Lao PDR, 9-11 May 2006 (2006).

17. Penot, E. Improving the productivity of Smallholder Rubber Agroforestry Systems: sustainable alternatives. Project frame, general proposals and on-farm trial methodology. Bogor (IDN) :, ICRAF, - 28 p., 4 tabl. ST: Working Paper (IDN) (1994).

18. Penot, E. and A. Gouyon. L'hévéaculture paysanne Indonésienne: Agroforêt et plantations clonales : des choix pour l'avenir. Séminaire CIRAD-MES: succès et échecs des révolutions vertes, Montpellier (FR), CIRAD (1995).

19. Penot, E. Project main features. Improving productivity of Indonesian rubber based agroforestry systems. Rubber Agroforestry Systems (RAS) as a challenge for the improvement of rubber productivity for smallholder through sustainability, 
biodiversity and environment. Introduction to Rubber Agroforestry Systems (RAS) in Indonesia. Bogor (IDN): ICRAF, - 28 p. (1996).

20. Penot, E. and Wibawa G. Improved Rubber Agroforestry Systems in Indonesia: an alternative to low productivity of jungle rubber conserving agroforestry practices and benefits. First results from on-farm experimentation in West-Kalimantan. IRRDB annual meeting, Beruwala, Sri Lanka, December (1996).

21. Penot, E. From shifting agriculture to sustainable rubber complex agroforestry systems (jungle rubber) in the peneplains of Sumatra and Kalimantan in Indonesia: innovations in local rubber based cropping systems. World Bank report "Indonesia: upland agricultural technology study. 1997/02, World Bank. Published as a WB report in 2002 (1997).

22. Penot, E. Prospects for the conservation of secondary forest biodiversity within productive rubber agroforests. CIFOR.USAID International Workhsop on" management of secondary forest in Indonesia", Bogor, Novembre 1997 (1997).

23. Penot, E. Associated trees with rubber in Rubber Agroforestry Systems (RAS). ICRAF workshop on "domestication of agroforestry trees", Gadjah Mada University, Jogyakarta, November 1997 (1997).

24. Penot, E. Budiman., A.F.S. Environmental aspects of smallholder rubber agroforestry in Indonesia : reconcile production and environment. International Rubber Conference, May 1998, Paris, France: 22 (1998).

25. Penot, E. L'amélioration des agroforêts à hévéa en Indonésie. Plantations, Recherche, Developpement. 5(n²/98, Mars/Avril 1998): 12 (1998)..

26. Penot, E., Ruf F., Courbet Ph. Tree crops triggers reforestation after deforestation in Indonesia? the case of rubber and cocoa : a comparison. Workshop on "When does technological progress in agriculture reduce deforestation?", CIFOR, Costa Rica, 11. - 12. March 1999 (1999).

27. Penot, E. Chambon B. "Les agroforêts à hévéas améliorées en Indonésie; mythe ou réalité?" PRD 2000, Novembre, (n 6) (2000).

28. Penot, E. Ruf. F. Rubber cushions the smallholder: no windfall, no crisis. In "Agriculture in crisis : people, commodities and natural ressources in Indonesia, 1996-2000" edited by F. Gerard and F Ruf. CIRAD/CURZON. CIRAD/CURZON. Richmond, UK, Curzon Press, UK: p 237-266 (2001).

29. Penot, E. Stratégies paysannes et évolution des savoirs : l'hévéaculture agroforestière indonésienne. Thèse de doctorat. Faculté des Sciences Economiques. Montpellier, Université Montpellier I.: 360p (2001).

30. Penot, E. Diversification of perennial crops to offset market uncertainties: the case of traditionnal rubber smallholders in West-Kalimantan, Indonesia. IFSA, Orlando, November 2002 (2002).

31. Penot, E., Wibawa G., Williams, S. Rubber Agroforestry Systems in Indonesia in Proceedings of the CIRAD/ICRAF workshop on Rubber Agroforestry Systems (RAS) as alternatives in Indonesia. Bogor, Indonesia, Septembre 1997. CIRAD/ICRAF, Bogor, Décembre 1999 (2001).

32. Penot, E. "Le foncier : l'enjeu de tous les dangers" ou les relations Etat paysans dans les grande plaines hévéicoles indonésiennes. Evolution des systèmes de production hévéicoles et gestion de la ressource foncière : le cas de la province de OuestKalimantan, Indonésie. Conférence UMR/SAGERT : Organisation spatiale et gestion des ressources et territoires ruraux, Montpellier, Février 2003, CIRAD (2003).

33. Penot E, Hébraud C. Modélisation et analyse prospective des exploitations hévéicoles en Indonésie : Utilisation du logiciel Olympe pour la définition de scénarios d'évolution en fonction de choix techniques et des aléas. Publié dans 
l'ouvrage co édité par Penot E. et Deheuvels O. « Modélisation des exploitations agricoles avec le logiciel Olympe ». Ouvrage collectif. Accepté par les éditions l'Harmattan, date de publication Janvier 2007 (2003).

34. Penot E. From Shifting Cultivation to Sustainable Jungle Rubber: A History of Innovations in Indonesia. Chapter 48 of the book Voices from the Forest Integrating Indigenous Knowledge into Sustainable Upland Farming. Malcolm Cairns, editor. 2006. Browse Book. 880 p. (2006).

35. Penot E. Editor, CD ROM : "10 années de recherche du SRAP en Indonésie : 1993-2003". Recueil de l'ensemble des publications de l'équipe du SRAP entre 1993 et 2003 (2004).

36. Penot E. Exploitations agricoles, stratégies paysannes et politiques publiques. Les apports du modèle Olympe sous la direction de Éric Penot. Editions Quae, Versailles. Collection «Update Sciences \& Technology. Janvier 2012.350 p. (2012).

37. Prasetyo LB and Kumazaki M. Land use changes and their causes in the tropics: a case study in South-Sumatra, Indonesia in 1969-1988. Tropics. 5,1/2 (1995).

38. Sethuraj, M. R. Impact of natural rubber plantations on environment. Seminar on National Rubber as an Environmenttally friendy raw material and a renewable resource. Trivandum, India -September 1996 (1996).

39. Schueller, W. Production et utilisation du matériel végétal amélioré d'hévéa brasiliensis par les petits planteurs de la province de Kalimantan Ouest, Indonésie. Mémoire de fin d'études ENITA. Bordeaux, Novembre 1997 (1997).

40. Sivanadyan K and Norhayati Moris. Consequences of transforming tropical rainforest to Hevea plantations. Presented at the FADINAP regional seminar on fertilization and environment, Chang Mai, Thailand. RRIM (1992).

41. Werner, S. Biodiversity of jungle rubber in West-Kalimantan. ICRAF/SRAP workshop on RAS (Rubber Agoforestry Systems), Bogor (1997).

42. Wan Abdul Rahaman, Wan Yacoob \& Jones K. Rubber as a green commodity. Paper presented at the International seminar on natural rubber as an environmentally friendly raw material and a renewable resource. Trivandum, India (1996). 